\title{
Koulutuksella arvostusta vanhustyöhön?
}

\author{
SIRPA VEHVILÄINEN, MARJA HARRI \& MATLEENA TAKALUOMA
}

\begin{abstract}
Miksi vanhustyön erikoistumiskoulutukseen hakeuduttiin? Millaiseksi osallistujat kokivat opiskelunsa merkityksen? Artikkeli käsittelee vanhustyön erikoistumiskoulutukseen hakeutumisen syitä ja sen koettuja merkityksiä. Lisäksi artikkelissa pohditaan saatujen tulosten hyödyntämistä vanhustyön käytännön, koulutuksen ja arvostuksen kannalta.
\end{abstract}

Y

hteiskunnan muutokset aiheuttavat muutostarpeita sen palvelujärjestelmiin. Muuttuvat työelämän rakenteet vaikuttavat vanhustyöhön kohdistuviin osaamisvaatimuksiin (Pelttari 1997, Rauma 2004). Vanhustyö kokonaisvaltaistuu, sen tehtävät ja toimintaympäristöt monimuotoistuvat. Tietotekniikan lisääntyminen tuo myös omat haasteensa vanhustyöhön. Tämän vuosituhannen erityisenä tehtävänä on kehittää vanhusten palveluja ja aktivoida koko yhteiskunta edistämään ikääntyneiden itsenäistä kotona asumista. Tulevaisuuden skenaarion mukaan hyvin iäkkäiden vanhusten määrän kasvaessa lisääntyy myös niiden sairastavien määrä, jotka tarvitsevat erilaisia vanhustyön palveluja. (Sonkin ym. 2001.)

Viime vuosikymmenien aikana vanhuskäsitys on laajentunut ja muuttunut. Vanhus mielletään toisin kuin ennen, passiivisesta palvelujen käyttäjästä on tullut aktiivinen toimija. (Paasivaara ym. 2000.) Muutoksien myötä ovat vanhustyön haasteet ja koulutusvelvoitteet myös muuttuneet.

Ammattikorkeakoulun tehtävänä on kouluttaa ammattitaitoisia asiantuntijoita, joilla on valmiudet itsensä ja työyhteisönsä jatkuvaan kehittämiseen. Koulutuksen tulee vastata työelämän asettamiin vaatimuksiin, jolloin tarvitaan käytännön tilanteisiin sovellettavaa ajantasaista tietoa. (L 255/ 1995; Raij 2003). Ajan tarpeisiin vastaava hoidon laatu ei synny itsestään, vaan tarvitaan työelämän tarpeisiin sopivaa käytännön tietoa, monialaista yhteistyötä ja arjen käytäntöjä uudistavaa ymmärrystä. (Mezirow 1996; Eteläpelto \& Tynjälä 1999.)

Koulutuksen ja sen merkityksen arviointi on tärkeää, sillä sen tehtävänä on tuottaa tietoa koko yhteiskunnalle, päätöksentekijöille, koulutuksen parissa työskenteleville, opiskelijoille sekä työelämälle. (Leino-Kilpi ym. 1995.) Parhaat valmiudet arvioida toimintaansa ja siihen yhteydessä olevia tekijöitä on toimijoilla itsellään. Arviointi edellyttää kokemusten kriittistä reflektointia sekä kokemustiedon liittämistä aihealueen tietoperustaan. (Schön 1995, Mezirow 1996, Vaherva 1999, Kauppi ym. 2003.) Kehittävä arviointi on apuväline uuden ymmärryksen tavoittamiseen ja hoitotyön koulutuksen kehittämiseen. Vanhustyön arviointi on erityisen tarpeellista myös sen vuoksi, koska vanhustyön koulutuksiin hakeutuminen on ollut vähäistä. Vanhustyötä ei koeta houkuttelevaksi eikä haasteelliseksi etenkään nuorten keskuudessa. (Parikka 2004.)

Tarkastelemme artikkelissamme kahden eri Aktivoiva vanhustyö -erikoistumisopintoihin osallistuneiden terveysalan työntekijöiden kokemuksia koulutuksestaan. Ensisijaisena kohderyhmänä ovat vuonna 2003 erikoistumisopintoihin osallistuneet opiskelijat, mutta tuloksissa kuvaamme osittain myös vuonna 2006 erikoistumisopintoihin osallistuneiden opiskelijoiden kokemuksia. Pohdimme myös koulutuksen tuomia merkityksiä vanhustyön arvostuksen kannalta.

\section{Aktivoiva vanhustyö}

Vanhustyö nähdään ammatillisena toimintana, jonka päämääränä on edistää iäkkään ihmisen hyvinvointia ja elämänlaatua sekä lisätä hänen elämänhallintaansa ja turvallisuuttaan (Koskinen ym. 1998). Vanhustyö on moniammatillista työtä siinä mielessä, että sitä tekevät monen alan ammattilai- 
set, kuten lääkärit, sosiaalityöntekijät ja hoitotyöntekijät. Vanhusten hoitotyö on siis yksi tärkeä osa vanhustyötä. Vanhusten hoitotyön tiedeperusta on hoitotieteessä. Vanhusten hoitotyön päämääränä on vanhuksen hyvinvointi ja se että hän voisi toimintakyvyn vajauksistaan huolimatta elää mahdollisimman täysipainoisesti ja lopulta kohdata rauhallisen ja kivuttoman kuoleman.

Aktivoiva vanhustyö perustuu sellaiseen ihmiskäsitykseen, jonka mukaan ihmisen elämä muodostuu hänen aktiviteeteistaan toisten kanssa. Tärkeää on aktiivisuus, tasapaino, sopeutuminen roolien menetyksiin ja elämään tyytyväisyys. Ajatellaan, että onnistuneessa vanhuudessa vanhus pysyy aktiivisena. Siksi aktivoivan vanhustyön päämääränä on luoda edellytyksiä mielekkäälle toiminnalle ja osallisuudelle tasavertaisena kansalaisena painottaen vanhan ihmisen omia voimavaroja ja omatoimisuutta. (Koskinen ym. 1998, Rintala 1999, Jyrkämä 2001.)

Aktivoivan vanhustyön ammatillisia erikoistumisopintoja varten laadittiin opetussuunnitelma sosiaali- ja terveysalalla vanhusten parissa työskenteleville henkilöille, joilla on vähintään opistoasteen tai ammattikorkeakoulututkinto (Opetussuunnitelma 2003).

Aktivoivan vanhustyön erikoistumisopinnoilla oli tarkoitus kehittää työelämässä toimivien henkilöiden ammatillista osaamista ja asiantuntijuutta. Työ- ja oppijakeskeistä ajattelutapaa haluttiin vahvistaa mahdollistamalla opiskelijoiden omakohtaisesti laatimat opiskelusuunnitelmat. Näin lisättiin opiskelijoiden sitoutumista omaan oppimiseensa ja saatiin sisältö säädeltyä mahdollisimman paljon vastaamaan työelämän tarpeita (Harvey \& Green 1993). Muita opintojen toteutumista ohjaavia periaatteita olivat avoin oppimisympäristö, ammatillisuus, yhteisöllisyys ja aktivoituminen. Avoin oppimisympäristö antoi opiskelijalle vapautta opiskelunsa toteutuksessa. Ammatillisuus tarkoitti käytännönläheisyyttä ja opintojen tiivistä yhteyttä työelämään. Yhteisöllisyys toteutui opiskelijoiden erilaisten kokemusten jakamisena, toisilta oppimisena ja yhteistyötaitojen kehittymisenä. Aktivoitumisen periaatteen tavoitteena oli toisaalta opiskelijoiden motivoituminen itsensä kehittämiseen ja toisaalta saada uusia valmiuksia vanhustyöhön. Opintojen pääsisältöalueita olivat vanhuus ja hyvä elämä, vanhustyön kehittäminen ja johtaminen sekä aktivoivan vanhustyön menetelmät.

\section{Tutkimuksen toteuttaminen}

Tutkimustehtävät olivat

1. Miksi koulutukseen hakeuduttiin?

2. Millaiseksi osallistujat kokivat opintojensa merkityksen opiskelun lopussa?

Tutkimuksen ensisijaisena kohderyhmänä olivat 20 vuonna 2003 erikoistumisopintoihin osallistunutta opiskelijaa. Heiltä aineisto ensimmäiseen tutkimustehtävään koottiin opiskelijoiden vastauksista koulutuksen alussa esitetyihin kysymyksiin. Toisen tutkimustehtävän aineisto koottiin koulutuksen lopussa opiskelijoiden tekemistä henkilökohtaisista opiskelusuunnitelmista ja koulutuksen arvioinneista. Vuoden 2006 17:lle erikoistumisopintoihin osallistuneelle opiskelijalle ei koulutuksen alussa esitetty kysymyksiä liittyen ensimmäiseen tutkimustehtävään. Aineisto toiseen tutkimustehtävään saatiin koulutuksen lopussa opiskelijoiden tekemistä koulutuksen arvioinneista.

Molempien ryhmien aineistot analysoitiin laadullisella sisällön analyysillä. Analyysiyksiköksi valittiin ajatuskokonaisuus. Aineistosta poimittiin tutkimustehtävän kannalta merkittävät ajatuskokonaisuudet. Nämä kirjoitettiin pelkistetysti ilmaistuina listoiksi. Pelkistetty ilmaisu oli lyhyt kuvaus ajatuskokonaisuudesta. Siinä on käytetty kuitenkin tarkasti alkuperäisen tekstin termejä. Analyysin seuraava vaihe oli ryhmittely. Samaa asiaa tarkoittavat ilmaisut yhdistettiin saaman ryhmään. Ryhmille annettiin sen sisältöä kuvaava nimi (alakategoria). Analyysiä jatkettiin niin että samansisältöiset ryhmät yhdistettiin ja yhdistetyille ryhmille (yläkategoria) annettiin sitä kuvaava nimi. (Polit \& Hungler 1995, Kyngäs \& Vanhanen 1999.)

\section{Koulutukseen hakeutuminen}

Opiskeluun hakeutumisen syistä muodostui kolme yläkategoriaa: työ, oma kehittyminen ja tarjottu koulutus.

Työhön sisältyi kolme alakategoriaa: Työn vaatimukset, työn kehittäminen ja uusi työ. Työ vanhusten parissa koettiin mieluisaksi, mutta vaativaksi. Työ koettiin vaativaksi, koska asiakkaat tarvitsevat entistä vaativampaa hoitoa ja lisäksi hoitomenetelmät muuttuvat ja niitä pitäisi pystyä myös itse kehittämään. Oman työyhteisön kehittämiseen koettiin tarvetta ja kiinnostusta, mutta omia kykyjä haluttiin parantaa. Työssä tulleet 
riittämättömyyden kokemukset antoivat sysäyksen opiskeluun. Haluttiin saada uusia näkökulmia rutiineiksi muodostuneisiin työtapoihin. Myös ajankäyttöä omassa työssä haluttiin järkeistää.

Opiskeluun hakeutumisen syynä oli myös toive uudenlaisesta työstä, työpaikasta tai virasta. Alan erikoistumiskoulutus nähtiin arvokkaana asiana uutta työtä hankittaessa. Harkinnassa oli myös oman yrityksen perustaminen.

Oma oppiminen sinänsä mainittiin työelämään liittyvien asioiden ohella myös opiskeluun hakeutumisen syyksi. Tähän sisältyi omasta jaksamisesta huolehtiminen:

”Koen, että jaksaakseni vielä vuosia työssä tarvitsen motivaatiota, jota ehkä saan opiskelusta, kun opin näkemään asiat eri tavalla."

Koulutukselta toivottiin nimenomaan jotain itselle, omalle persoonalliselle kehitykselle sekä vahvistusta ammatti-identiteetille. Kiinnostuksen ja innostuksen lähteenä mainittiin myös aikaisemmat omat opinnot, jotka olivat käynnistäneet lisäoppimisen tarpeen.

Opiskeluun hakeutumisen syyksi ilmeni myös tarjottu koulutus sinänsä. Koulutuksen sisältö, opetussuunnitelma, opintojen laajuus ja ajankohta sekä toteutus-suunnitelma olivat itselle sopivat:

"Koulutus tuntui minun tarpeisiini tehdyltä."

Koulutus nähtiin käytännönläheisenä ja kiinnostavana. Ajankohta oli sellainen, että koulutus sopi omaan elämän- ja työtilanteeseen. Koulutuksen esitteestä sai käsityksen, että opinnot muodostivat laajan kokonaisuuden, mutta niistä oli mahdollista selvitä työn ohessa.

\section{Koulutuksen koetut merkitykset}

Opintojen merkitystä kuvattiin itsessä tapahtuneena muutoksena sekä itsessä työyhteisön jäsenenä ja työyhteisössä tapahtuneena muutoksena.

Itsessä koulutuksen aikana tapahtuneena muutoksena opiskelijat toivat esille sen, että heidän tiedonhankintataitonsa olivat kehittyneet. Tutkimukset olivat tulleet tutuiksi, niiden etsiminen koettiin entistä helpompana. Myös ATK-taidot olivat kehittyneet. Koulutus oli lisännyt tiedon halua ja antanut innostusta jatko-opintoihin. Koulutuksen aikana paljastui monia alueita, joissa vielä riittää opettelemista. Koulutus oli siis aktivoinut opiskelijoita itsensä kehittämiseen.

Myös toisen ryhmän opiskelijat kuvasivat tiedonhankintataitonsa kehittyneen ja kokivat oppi- neensa hankkimaan paremmin tutkittua tietoa. Koulutus oli myös lisännyt tiedon halua ja kiinnostusta itsensä kehittämiseen. Tulevaisuuden jatkokoulutus tarpeet liittyivät opiskelijoilla hyvin erilaisiin osa-alueisiin, painottuen kuitenkin hoitotieteeseen, vanhustyöhön ja johtamiseen.

Itsessä tapahtuneesta kehittymisestä opiskelijat mainitsivat vielä, että kriittinen tiedostaminen oli lisääntynyt. He pohtivat entistä kriittisemmin itseään, omaa toimintaansa sekä työkäytäntöjä sekä etsivät perusteluja ja tavoitteita työlle:

"Olen ruvennut kiinnittämään huomiota itseeni, omaan jaksamiseeni ja kehittämiseeni."

Koulutus oli myös antanut rohkeutta ottaa kantaa keskusteluihin ja tuoda perusteltuja muutosehdotuksia.

Samanlaisia kriittisyyden ja rohkeuden tuntemuksia kuvasi toinenkin opiskelijaryhmä. Koulutuksen myötä omia työtapoja tarkasteli kriittisemmin ja rohkeus omien perusteltujen näkemyksien esittämiseen oli kasvanut. Koulutus oli antanut myös tervettä itseluottamusta omiin näkemyksiin ja oma ammatillinen kasvu oli vahvistunut ja kasvanut.

Opintojen merkityksistä itselle työyhteisön jäsenenä ja työyhteisölle nousi esille neljä alakategoriaa, joissa koettiin tapahtuneen muutosta.

Nämä olivat asenne, näkökulmat, yhteistyötaidot ja kehittäminen.

Arvioinneista ilmeni selkeästi, että asenne työhön oli koulutuksen myötä muuttunut entistä kriittisemmäksi ja aktiivisemmaksi. Lisätieto, asioiden pohdinta ja sitä kautta parantunut ymmärrys toi myös lisää intoa tehdä omaa työtä ja kehittää sitä. Arveltiin, että työilmapiiri oli muuttunut avoimemmaksi uusille ideoille:

”Olen saanut hyvää palautetta ideoista, joita olen työyhteisöön vienyt."

Ammatillisen koulutuksen merkitystä ja tarvetta oli yhdessä työtovereiden kanssa pohdittu. Opiskelijat kokivat, että heidän koulutustaan arvostettiin työyhteisössä ja siitä oli hyötyä muillekin. Hyvänä oli koettu se, että samasta työyhteisöstä oli useampia opiskelijoita. Tällöin yhteinen pohdinta käynnistyi helposti.

Myös vuoden 2006 erikoistumisopintojen opiskelijat kuvasivat koulutuksen vaikuttaneen asenteisiin. Koulutus oli lisännyt intoa ja halua työn kehittämiseen. Opiskelijat toivoivat olevansa hyvä esimerkki muille työyhteisön jäsenille hoitotyön kehittämisestä.

Koulutuksen myötä opiskelijoiden näkökulmat 
olivat muuttuneet entistä laajemmiksi. Näin arveltiin tapahtuneen jossain määrin myös koko työyhteisössä. Uusia tietoja oli viety työtovereille ja niistä oli pidetty koulutustilaisuuksia. Näkökulman laajenemisesta kertoo sekin että ammatillisen lisäopiskelun tarve tiedostettiin:

”Olen esimerkkinä muille, että kannattaa opiskella. Koulutus tukee jokapäiväisessä työnteossa minua."

Myös toinen opiskelijaryhmä kuvasi näkökulmansa laajentuneen koulutuksen myötä. Omaan työhön oli saanut laaja-alaisuutta ja koulutus oli antanut uutta näkökulmaa myös muihin yhteistyötahoihin. Koulutuksessa saatua tietoa oli pystynyt hyvin soveltamaan ja hyödyntämään omassa työssä ja se oli antanut uusia ideoita ja välineitä oman työn kehittämiseen.

Yhteistyötaidot muodostuivat yhdeksi alakategoriaksi kuvattaessa itsessä työyhteisön jäsenenä tapahtunutta muutosta:

"Kiinnostus yhteistyön kehittämiseen tiimissä heräsi ja tällä hetkellä onkin muutosta tapahtunut parempaan suuntaan."

Lisäksi yhteistyötä omaisten kanssa tarkasteltiin ja kehitettiin eteenpäin.

Kehittäminen oli neljäs alakategoria, joka kuvasi itsessä työyhteisön jäsenenä tapahtunutta muutosta. Kehittämiselle antoi lisäpotkua se, että koulutus oli asettanut opiskelijat ajattelemaan omaa työtään eri näkökulmista. Muutoksen tarpeet ja mahdollisuudet tulivat näin entistä helpommin esille. Kehittävä ote työhön oli vahvistunut. Opiskelijat tekivät erikoistumistyön, joka usein kohdistui oman työyhteisön kehittämiseen. Työyhteisöön tehdyn kehittämistyön merkitystä korosti se, että näin opiskelulla koettiin olevan todellista ja konkreettista hyötyä.

Myös vuoden 2006 opiskelijoiden erikoistumistyö liittyi usein oman työn tai työyhteisön kehittämiseen. Erikoistumistyön koettiin hyödyttävän hyvin omaa työyhteisöä ja sen toivottiin tuovan konkreettista hyötyä työhön. Koulutus oli myös aktivoinut hankkimaan tietoa enemmän ja lisännyt halua kehittää hoitotyötä myös tulevaisuudessa.

Työyhteisössä tapahtunutta muutosta kuvaavat alakategoriat olivat uudet toimintatavat, asennoituminen ja opiskelun arvostus.

Uusia toimintatapoja oli kehitetty erilaisissa oppimistehtävissä, lähinnä erikoistumistyössä. Niitä oli jo viety käytäntöön tai ainakin suunniteltiin aloitettaviksi. Näistä uusista toimintatavoista mainittakoon ennaltaehkäisevät kotikäynnit, joita käynnistettiin opiskelijoiden erikoistumistyön avulla. Uudenlaista toimintaa ja helpotusta työhön toivat myös laadun varmistamisen ohjeistukset, uudenlaiset yhteistyömuodot ja uusi tieto, jota opiskelijat veivät yhteisöihinsä.

Koulutuksen myötä uusia toimintatapoja oli kehitetty myös toisessa opiskelijaryhmässä. Koulutus oli tuonut työyhteisöön uusia toimintatapoja ja työyhteisön tiedot olivat ajanmukaistuneet opiskelijan kautta. Erikoistumistyöt vastasivat hyvin työyhteisön tarpeita ja niitä oli tarkoitus ottaa käyttöön työyhteisöissä. Osittain erikoistumistöiden toteutus ja edelleen kehittäminen laajentui myös työyhteisön ulkopuolelle. Erikoistumistöistä oli siis konkreettinen hyöty työyhteisölle.

Asennoituminen oli toinen alakategoria, joka kuvasi muutosta työyhteisössä. Oman opiskelun arveltiin käynnistäneen asennoitumisen muutosta työtovereissa. Todettiin, että innostus työn laadun parantamiseen sekä kehittämiseen oli voimistunut. Oman työmotivaation nähtiin myös tarttuvan muihin. Tällä tavalla työilmapiiri muuttui positiiviseen suuntaan.

Koulutuksella oli ollut vaikutusta työyhteisön asenteisiin myös toisen ryhmän mielestä. Työntekijöiden muutoksen pelko oli vähentynyt ja työyhteisöön oli tullut uskallusta kokeilla uutta. Opiskelijat uskoivat koulutuksen herättäneen ja lisänneen myös työyhteisön kiinnostusta hoitotyön laadun kehittämiseen.

Opiskelun arvostus nousi myös esille muutosta työyhteisössä kuvaavana tekijänä. Oma kokemus siitä että opiskelu on ollut hyödyllistä, toi työtovereillekin uskoa siihen, että opiskelu kannattaa ja kouluttautumisen arvostus työyhteisössä nousee. Samoin vuoden 2006 opiskelijat kuvasivat työyhteisön ilmapiirin muuttuneen koulutusmyönteisemmäksi.

\section{POHDINTAA}

\section{Tutkimuksen luotettavuus}

Tässä tutkimuksessa ensisijaisena kohderyhmänä olleiden tiedonantajien määrä ja ryhmä oli selkeästi rajattu, sillä tiedonantajina toimivat kaikki erikoistumisopintoihin osallistuvat opiskelijat. Tutkimukseen osallistuminen oli vapaaehtoista. Tutkimuksen ensisijaiselle kohderyhmälle, vuoden 2003 erikoistumisopintoihin osallistuville opiske- 
lijoille, tiedotettiin tutkimuksesta ja siihen osallistumisesta sekä suullisesti että kirjallisesti. Koulutukseen osallistuvien henkilöllisyys oli tiedossa ja henkilökohtaiset opiskelusuunnitelmat olivat nimellä varustettuja, samoin kuin alkukyselyn lomakkeet. Tutkimuksen aihe ei kuitenkaan ollut kovin arkaluontoinen, joten nimellä esiintyminen tuskin altisti opiskelijoita peittelemään, kaunistelemaan tai muuttamaan arviointiaan. Loppukyselyn palautelomakkeet palautettiin nimettöminä joko tutkijoiden postilokeroihin tai lähetettiin postitse. Vain yksi palautelomake jäi palauttamatta. Vuoden 2006 opiskelijoilta pyydettiin koulutuksen lopussa kirjalliset palautteet nimettöminä. Kahdeksan opiskelijaa palautti lomakkeen. Heiltä lupa käyttää aineistoa saatiin jälkikäteen sähköpostin kautta.

Laadullisen tutkimuksen luotettavuutta arvioitaessa huomio kohdistetaan tutkijaan, aineiston keräämiseen, aineiston laatuun, aineiston analysointiin ja tutkimuksen raportointiin (Latvala \& Vanhanen-Nuutinen 2001). Tutkimusaineisto kerättiin siltä kohderyhmältä ja siitä ympäristöstä, josta tutkimustehtäviin voitiin saada vastaus. Käytetyillä aineistonkeruutavoilla saatiin laadukasta aineistoa, sillä kysymyksiin oli vastattu perusteellisesti ja huolellisesti. Opiskelijoiden hyvät pohdinta- ja arviointitaidot tulivat esille henkilökohtaisissa kirjallisissa opiskelusuunnitelmissa. Opiskelijoilla oli kriittisyyttä ja kykyä arvioida oman koulutuksensa merkitystä. Koulutuksen merkityksen tutkimiseen käytetyt kaksi aineistoa täydensivät toisiaan ja siten lisäsivät tulosten luotettavuutta.

Sisällön analyysin kautta saatuihin tutkimustuloksiin ei ole olemassa yhtä tulkinnallista totuutta, vaan tulkinnassa on aina mukana tutkijan oma löytävä mieli. (Nieminen 1997.) Luotettavien päätelmien kannalta on kuitenkin olennaista aineiston luokittelun onnistuminen ja tutkijan on kyettävä osoittamaan yhteys tuloksen ja aineiston välillä (Latvala \& Vanhanen-Nuutinen 2001). Tässä tutkimuksen ensisijaisen kohderyhmän aineiston analyysin luotettavuutta lisättiin käyttämällä face- validiteettia esittämällä tulokset henkilölle, joka oli jo aikaisemmin analysoinut alkuperäistä aineistoa. Luotettavuuden lisäämiseksi on tutkimuksen raportoinnissa esitetty muutamia tutkittavien alkuperäisilmauksia kuvaavia tyypillisimpiä ilmauksia.

Tulosten luotettavuuteen saattaa vaikuttaa se, että opiskelijoiksi hakeutuneet olivat keskimääräistä motivoituneempia, koska olivat odottaneet jo kauan tällaista koulutusta. Tämä voi olla yhteydessä tutkimuksessa saatuihin myönteisiin tuloksiin.

\section{Osaamisen haasteet}

Vanhustyön ammattilaisten tietotaidoissa on tutkimusten mukaan kehittämistarpeita (Opetussuunnitelma 2003). Hyvä lähtökohta oppimiselle on koulutukseen hakeutumisen vapaaehtoisuus ja motivaatio itsensä kehittämiseen, jotka nousivat esille tämän tutkimuksen tuloksissa. Koulutukseen hakeutumisen syitä olivat työn muuttuminen entistä vaativammaksi, hoitomenetelmien kehittyminen sekä tarve oman itsensä ja työnsä kehittämiseen.

Vanhustyöhön saatu peruskoulutus ja vuosien työkokemus eivät enää tänä päivänä riitä, vaan jokaisen työntekijän on tärkeää päivittää omaa ammatillista osaamistaan. Yksilön osaamisen kehittämisellä on myönteinen vaikutusta koko työyhteisöön, mikä tuli esille myös tässä tutkimuksessa. Tiedollisten ja taidollisten valmiuksien lisäksi vanhustyö vaatii tekijältään tiettyä kypsyyden tasoa, kykyä käsitellä työn herättämiä tunteita ja nähdä työ myönteisessä mielessä haasteelliseksi, mielenkiintoiseksi ja monipuoliseksi. (Isola 1998.) Merkittävää vanhustyön osaamisessa on työntekijän oma persoonallisuus ja itsensä tunteminen. Ellei vanhustyöntekijä tiedosta omia vahvuuksiaan, kehittämisalueitaan tai ei luota omiin kykyihinsä, ne saattavat heikentää työssä jaksamista. (Rauma 2004.)

Tutkimusten tulosten perusteella näyttäisi siltä, että opiskelijat kokivat saamansa koulutuksen merkityksen itselleen tärkeäksi ja myös työyhteisölleen hyödylliseksi. Koulutus täytti opiskelijoiden odotukset. Myös järjestäjien asettamat tavoitteet ammattitaidon kehittymisestä ja ammatillisen osaamisen ja asiantuntijuuden vahvistumisesta saavutettiin. Koulutuksen voidaan sanoa olleen tuloksellinen ja se on ollut tarkoituksenmukainen työelämän kehittämisen kannalta. On yleisesti tunnettua, että koulutuksella ja opiskelulla on myönteisiä vaikutuksia (vrt. Korte 1997 ), mutta vaikutusten pysyvyys on epävarmaa. Tämän vuoksi olisi tärkeää pohtia, miten opiskelun myönteiset vaikutukset saadaan säilymään myös tulevaisuudessa. 


\section{Imagon metsästys}

Tulevaisuudessa vanhusten määrän lisääntyminen ja hoitoalalla tapahtuva eläköityminen johtaa tilanteeseen, jossa tarvitaan lisää vanhustyöntekijöitä (Paulin 2003). Vanhustyöhön suunnattuun koulutukseen ei kuitenkaan ole ollut tungosta, eikä työ vanhusten parissa ole kiinnostanut nuoria. Ilmeisesti nuoret ihmiset eivät koe vanhusten hoitotyötä haasteellisena tai vaativana. Herääkin kysymys kulttuurien vaikutuksesta vanhustyön kiinnostavuuden määrittäjänä (Paasivaara ym. 2000). Vanhusten asema ja arvostus ovat teollistumisen ja kaupungistumisen myötä ehkä heikentyneet ja vanhukset ovat jääneet taka-alalle. Vanhustyön profiilia tulisi nostattaa sekä yksilö- että yhteiskuntatasolla. Vanhustyön erikoistumisopintojen myötä voidaan luoda myönteistä mielikuvaa ja synnyttää kiinnostusta vanhustyötä kohtaan ja siihen kouluttautumiseen, kuten tästä tutkimuksesta kävi ilmi.

\section{Yhteys työelämään}

Vanhustyöntekijänä kehittyminen on tiiviisti yhteydessä työelämään. Työ antaa kimmokkeen koulutukseen hakeutumiseen ja koulutuksen sisällöt pitää rakentaa työn tarpeiden pohjalta. Opetussuunnitelman tulee olla joustava ja avoin, jotta koulutuksen aikana ilmenevät muutostarpeet voidaan ottaa huomioon. Joustavuus ja avoimuus lienee siis tärkeää säilyttää myös tulevissa koulutuksissa, sillä tulosten mukaan opiskelun avoimuus houkuttelee opiskelemaan ja mahdollistaa opintojen osuvuuden omiin tarpeisiin.

Toteutuneesta opiskelusta oli koettu olleen hyötyä työhön ja työyhteisöön. Erityisesti työyhteisön kanssa suunnitellut kehittämistehtävät olivat antoisia. Kehittämistehtävien tulosten raportointi toimii luontevasti myös työyhteisön koulutuksena. Kehittämistehtävin merkitystä voidaan edelleen vahvistaa niin, että ne suunnataan mittatilaustöinä tiettyjen työyhteisöjen tarpeisiin. Oman ja työyhteisön kehittymisen kannalta näyttää olevan hyödyllistä, että samasta työyhteisöstä osallistuu enemmän kuin yksi opiskelija. Tällöin työskentelyn kriittinen reflektointi ja suunnitelmien soveltaminen käytäntöön onnistuvat luontevasti. Näkemysten laajentumiselle on kuitenkin tärkeää, että opiskelijoita on myös erilaisista työyhteisöistä ja -ympäristöistä, sillä moniammatillisuus auttaa integroimaan eri alojen tietoa, näkemyksiä ja osaamista vanhustyöhön kehittämiseksi.

Näihin tuloksiin perustuen voidaan todeta, että koulutuksella on myönteinen vaikutus sekä oman itsensä, työyhteisön ja koko vanhustyön kehittymiseen. On siis tärkeää jatkaa ja edelleen kehittää vanhustyöhön liittyviä erikoistumisopintoja ja kouluttaa erinomaisia vanhustyön asiantuntijoita sekä näin nostaa vanhustyön arvostusta.

\section{Lähteet}

Eteläpelto, A. \& Tynjälä, P. (1999). Oppiminen ja asiantuntijuus. Työelämän ja koulutuksen näkökulmia. Helsinki: WSOY.

Harvey, L. \& Green, D. (1993). Defining quality. Assessment \& Evaluation in Higher Education, 18 (1), 9-34.

Isola, A. (1998). Arvostammeko vanhuksiamme? Hoitotiede 10, 189-190.

Jyrkämä, J. (2001). Vanheneminen ja vanhuus. Teoksessa Sankari, A. \& Jyrkämä, J. (toim.) Lapsuudesta vanhuuteen. Iän sosiologiaa. Tampere: Osuuskunta Vastapaino, 267-314.

Kauppi, A., Hanski, K., Nousiainen, R. \& Lahtiranta, K. (2003). Arviointi pedagogisena kehittämisen välineenä. Teoksessa Kotila, $\mathrm{H}$. (toim.) Ammattikorkeakoulupedagogiikka. Helsinki: Edita Prima OY, 255-270.

Korte, R. (1997). Hoitohenkilöstön täydennyskoulutus. Selvitys täydennyskoulutuksen nykytilasta ja kehittämistarpeista. Tehy ry: Ammatti- ja koulutusasiain osasto. Sarja B: Selvityksiä 7/1997.

Koskinen, S., Aalto, L., Hakonen, S. \& Päivärinta, E. (1998). Vanhustyö. Helsinki: Vanhustyön keskusliitto.

Kyngäs, H. \& Vanhanen, L. (1999). Sisällön analyysi. Hoitotiede 11, 13-22.

Latvala, E. \& Vanhanen-Nuutinen, L. (2001). Laadullisen hoitotieteellisen tutkimuksen perusprosessi: sisällönanalyysi. Teoksessa Janhonen, S. \& Nikkonen, M. (toim.) Laadulliset tutkimusmenetelmät hoitotieteessä. Helsinki: Bookwell Oy, 21-43.

L 255/1995. Laki ammattikorkeakouluopinnoista. Suomen asetuskokoelma.

Leino-Kilpi, H., Hupli, M. \& Räisänen, A. (1995). Terveydenhuollon koulutuksen tulokselli- 
suus ja laatu. Arviointi 5/1995. Opetushallitus. Helsinki: Yliopistopaino.

Mezirow, J. (1996). Uudistava oppiminen. Kriittinen reflektio aikuiskoulutuksessa. Helsinki: Helsingin yliopiston Lahden tutkimus- ja koulutuskeskus.

Nieminen, H. (1997). Kvalitatiivisen tutkimuksen luotettavuus. Teoksessa Paunonen, M. \& Vehviläinen-Julkunen, K. Hoitotieteen tutkimusmetodiikka. Helsinki: WSOY, 215-221.

Opetussuunnitelma (2003). Vanhustyön ammatilliset erikoistumisopinnot. Lahden ammattikorkeakoulu, Sosiaali- ja terveysalan laitos.

Paasivaara, L. Backman, K. \& Nikkonen, M. (2000). Apuhoitajana vanhustyössä: elämänkertatutkimus. Hoitotiede (12) 5, 251-259.

Parikka, T. (2004). Ammattikorkeakoulun jatkotutkinto vanhustyön osaamisen kehittäjänä. Teoksessa Olkkonen, E. (toim.) Ammattikorkeakoulun jatkotutkinto - toteutuksia ja kokemuksia. Hämeen ammattikorkeakoulu, Hämeenlinna, 166-167.

Paulin, R. (2003). Sosiaali- ja terveysalan valmistelutyö. Teoksessa Olkkonen, E. (toim.) Ammattikorkeakoulun jatkotutkinto - lähtökohdat ja haasteet. Hämeenlinna: Hämeen ammattikorkeakoulu, 23-28.

Pelttari, P. (1997.) Sairaanhoitajan työn nykyiset ja tulevaisuuden kvalifikaatiovaatimukset. Tutkimuksia 80. Helsinki: Stakes.
Polit, D. \& Hungler, B. (1995). Nursing research. principles and methods. J B Lippincott Company, Philadelphia.

Rauma, M. (2004). Turvapuhelinpalvelut vanhustyössä. Osaamisen haasteet palvelutalossa. Teknillisen korkeakoulun Lahden keskus. Julkaisusarja WWW.aluenet.com.

Rintala, T. (1999). Miten vanhuskäsitys voi heijastua palveluihin. Gerontologia 13(2): 92-99.

Raij, K. (2003). Osaamisen tuottaminen ammattikorkeakoulun päämääränä. Teoksessa Kotila, H. (toim.) Ammattikorkeakoulupedagogiikka. Helsinki: Edita Prima OY, 42-58.

Schön, D. A. (1995). The Reflective practitioner. How professionals think in action. New York: Basic Books.

Sonkin, L., Petäkoski-Hult, T., Rönkä, K. \& Södergård, H. (2001). Seniori 2000. Ikääntyvä Suomi uudelle vuosituhannelle. Suomen itsenäisyyden juhlarahasto Sitra. Helsinki: Yliopistopaino.

Terveys 2015 -kansanterveysohjelma. Sosiaali- ja terveysministeriön julkaisuja 2001:4.

Vaherva, T. (1999). Henkilöstökoulutuksen rajat ja mahdollisuudet. Teoksessa Eteläpelto, A. \& Tynjälä, P. (toim.) Oppiminen ja asiantuntijuus. Työelämän ja koulutuksen näkökulmia. Helsinki: WSOY, 83-101. 